\title{
THE PREVALENCE OF PULMONARY TUBERCULOSIS IN A NORTHERN TRANSVAAL COPPER-MINE RELATED TO THE IMPORTANCE OF PRE-EMPLOYMENT RADIOGRAPHS
}

\author{
BY \\ G. E. DALTON \\ From the Messina (Transvaal) Development Co., Ltd.
}

(RECEIVED FOR PUBLICATION OCTOBER 22, 1956)

The importance of pre-employment chest radiography in the elimination of pulmonary tuberculosis from the mines is now widely recognized. In South Wales, mining entrants have been radiographed since 1940 but in the rest of Great Britain this has only become general since nationalization of the coal industry in 1948. In the U.S.A. the practice is not yet universal but varies with the firm. In the Union of South Africa all European employees in scheduled gold-mines have had pre-employment chest radiographs for many years; but this practice did not apply to a large number of unscheduled mines (gold, copper, or asbestos) nor to African labourers. Recent legislation (1956) has made pre-employment chest radiography of both European and African employees compulsory in most mines in the country. The inclusion of African miners in this scheme is important in view of the high prevalence of pulmonary tuberculosis among them. A recent survey in the Northern Transvaal (Union Government Committee of Enquiry into Pneumoconiosis and Tuberculosis, 1955-56) revealed a prevalence of tuberculosis of 7.8 per thousand in a rural African population. Dormer in 1943 found a prevalence for the same area of 23 per thousand. In the Bechuanaland Protectorate the prevalence was estimated to be 13 per thousand (1952) and in Kenya 11 per thousand (1949). Estimates for Nyasaland and the Rhodesias, from which a large proportion of the mine's African labour is recruited, are not available, but there is no reason to suppose that the incidence of tuberculosis in these countries differs much from the figures given. The latest available estimates for the Union of South Africa are up to 5 per thousand for Europeans and between 10 and 20 per thousand for non-Europeans (Viljoen, 1957).
Description of the Copper-mine

The copper-mine at which the surveys described in this paper were carried out is situated at Messina in the Northern Transvaal, nine miles from the Limpopo River. Mining has been carried out for 50 years and there are now four shafts descending to varying depths of up to 4,000 feet. The mining consists of excavating large areas and little work is done in narrow or confined spaces. Little water is encountered underground and temperature and humidity are not unduly high. Water sprays and atomizers are the chief means of controlling dust. Results of control are good and for dustiness the mine compares very favourably with other mines in the country.

About 2,000 Africans and 250 Whites are employed underground. The Africans are recruited from various sources including the Rhodesias and Nyasaland. A proportion have previously been employed in gold or asbestos mines in the south. They are not engaged for any definite period; some work a month or two, others for 20 years or longer with periods of home leave. There is consequently a high labour turnover of about $50 \%$ of the total complement per annum. There are no other industries in the neighbourhood, the surrounding African population being engaged mostly in farm work.

The African labourers are housed in compounds where both single and married accommodation is available. Adequate rations are issued to all employees and their families on a scale laid down by Government regulation. Neither housing nor malnutrition is therefore likely to be an important factor in causing the spread of tuberculosis. The climate of Messina is sub-tropical, the summers 
being hot, the winters mild, with an annual rainfall of approximately 13 inches.

The mine came within the requirements of the Union of South Africa Silicosis Act in September, 1953, and since then pre-employment chest radiography of white miners has been compulsory. Recent legislation has made it compulsory for both Europeans and Africans to have such an examination and Africans have in fact been radiographed since July, 1955. Before this time only clinical examination of the chest was carried out.

No detailed statistics are available of the prevalence of tuberculosis among the African employees before the present survey. Between 1938 and 1952, however, 156 patients suffering from pulmonary tuberculosis were admitted to the African hospitals serving the mine. The average total African labour force for this period was 3,673 giving a prevalence of tuberculosis of 4.2 per thousand per annum; 94 cases occurred in underground workers who averaged 1,855 over the same period. This gives an approximate rate in underground workers of $5 \cdot 1$ per thousand per annum. These rates can be considered to give only a very uncertain indication of the true rates as only the advanced cases were likely to be discovered and the actual prevalence of tuberculosis for 1938-52 must have been considerably higher than $5 \cdot 1$ per thousand.

Sixty-five per cent. of cases occurred in labourers who had had less than three years' service in the mine.

\section{First Mass Radiography Survey}

In September, 1953, a survey of all African underground workers was carried out by a unit of the Silicosis Medical Bureau. One thousand, nine hundred and forty-seven workers were radiographed and of these 156 were recalled for full-sized films, but 17 failed to attend either because they refused or because they had left the mine. The results are given in Table 1.

TABLE 1

CLASSIFICATION OF RADIOGRAPHS OF 156 WORKERS RECALLED FOR LARGE FILMS RESULTING FROM FIRST MASS RADIOGRAPHY SURVEY

\begin{tabular}{l|c|c|c|c}
\hline & $\begin{array}{c}\text { Large } \\
\text { Film }\end{array}$ & $\begin{array}{c}\text { Miniature } \\
\text { Film }\end{array}$ & Total & $\begin{array}{c}\text { Rate per 1,000 } \\
\text { of Population } \\
\text { Radiographed }\end{array}$ \\
\hline \begin{tabular}{l|c} 
Normal \\
Inactive tuberculosis
\end{tabular} & 33 & - & 33 & - \\
Clinically significant & 6 & 10 & 16 & $8 \cdot 2$ \\
tuberculosis & 46 & 3 & 49 & $25 \cdot 2$ \\
Silicosis & 23 & 2 & 25 & $12 \cdot 8$ \\
Silico-tuberculosis & 31 & 2 & 33 & $16 \cdot 9$ \\
\hline \multicolumn{1}{c|}{ Total } & 139 & 17 & 156 & \\
\hline
\end{tabular}

Sputum examinations were carried out on 93 of the 106 men with abnormal large films. In six of the cases of clinically significant tuberculosis and in eight of the cases of silico-tuberculosis, acid-fast bacilli were found, giving a prevalence of infectious tuberculosis of $7 \cdot 2$ per thousand of the population radiographed.

As a number of the radiographed employees left the mine, only 55 out of the 100 cases in which significant radiological abnormality had been detected were submitted to the Silicosis Bureau for certification. Of these $47(24 \cdot 1$ per thousand total radiographed) were certified (Table 2).

TABLE 2

CERTIFICATION OF TUBERCULOSIS OR SILICOSIS BY SILICOSIS BUREAU AFTER 1953 SURVEY

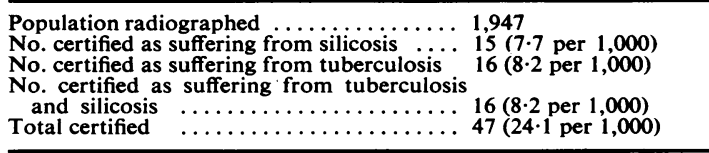

But for the lapses there would probably have been a considerably higher certification rate. All those certified as suffering from silicosis and/or tuberculosis were suspended from further mining activities, as required under the Silicosis Act, 1953. Thus a number of infectious and potentially infectious cases of tuberculosis were removed from mining employment. A few were allowed to continue in employment pending further examination.

Since July, 1955, all African recruits for both surface and underground mining have had a preemployment chest radiograph. Between July, 1955, and July, 1956, 2,432 recruits were examined and $10(4 \cdot 1$ per 1,000$)$ were rejected on account of clinically significant tuberculosis. No record is available of those rejected on account of silicosis.

\section{Second Mass Radiography Survey}

All African underground workers were again radiographed in June, 1956. The population radiographed was 1,936 and of these 63 were recalled for large films but two failed to attend. The results are shown in Table 3.

TABLE 3

CLASSIFICATION OF RADIOGRAPHS OF 63 WORKERS RECALLED FOR LARGE FILMS RESULTING FROM SECOND MASS RADIOGRAPHY SURVEY

\begin{tabular}{|c|c|c|c|c|}
\hline & $\begin{array}{c}\text { Large } \\
\text { Film }\end{array}$ & $\underset{\text { Milm }}{\text { Miniature }}$ & Total & $\begin{array}{c}\text { Rate per } 1,000 \\
\text { Population } \\
\text { Radiographed }\end{array}$ \\
\hline Normal & $\begin{array}{r}24 \\
4\end{array}$ & - & $\begin{array}{r}24 \\
4\end{array}$ & $\overline{2 \cdot 1}$ \\
\hline $\begin{array}{l}\text { Clinically significant } \\
\text { tuberculosis } \\
\text { Silicosis } \\
\text { Silico-tuberculosis }\end{array}$ & $\begin{array}{r}6 \\
25 \\
2\end{array}$ & $\begin{array}{l}1 \\
-\end{array}$ & $\begin{array}{r}7 \\
26 \\
2\end{array}$ & $\begin{array}{r}3 \cdot 6 \\
13 \cdot 4 \\
1 \cdot 0\end{array}$ \\
\hline Total & 61 & 2 & 63 & \\
\hline
\end{tabular}


Table 3 reveals a gratifying fall, compared with 1953 , in the prevalence of tuberculosis but shows no change in the prevalence of uncomplicated silicosis. One of the cases of clinically significant tuberculosis was found to have a positive sputum. This case, together with one of the remaining five in this group, was subsequently certified as suffering from tuberculosis by the Silicosis Medical Bureau. Of the other four patients in this group, one was certified as suffering from silico-tuberculosis, two returned to employment, and one deserted.

One of the cases of silico-tuberculosis had a positive sputum and was certified as suffering from tuberculosis only. The other case deserted after the taking of the large film.

In the second survey, therefore, only two cases were found to have acid-fast bacilli in the sputum, giving a prevalence of infectious tuberculosis of one per 1,000 of the population radiographed. No infectious tuberculosis was found in those with silicosis only.

\section{Comment}

The reduction in the prevalence of tuberculosis in the mine between 1953 and 1956 (Table 4) is striking and may be attributed to two factors. As a result of the first survey, Africans found to be suffering from tuberculosis were suspended from work in the mines and this must certainly have been the main cause for the reduction. In addition, the introduction of pre-employment chest radiography prevented the recruitment of cases of active tuberculosis which, if the figures for 1955-56 are considered representative, was taking place at the rate of about four cases per thousand new entrants.

TABLE 4

REDUCTION IN TUBERCULOSIS RATES AMONG UNDERGROUND AFRICAN COPPER-MINERS BETWEEN 1953 AND 1956

\begin{tabular}{l|c:c}
\hline & $\begin{array}{c}\text { Rate per 1,000 } \\
\text { Radiographed } \\
\text { (September, 1953) }\end{array}$ & $\begin{array}{c}\text { Rate per 1,000 } \\
\text { Radiographed } \\
\text { (June, 1956) }\end{array}$ \\
\hline Clinically significant tuber- & $25 \cdot 2$ & 3.6 \\
$\begin{array}{l}\text { culosis } \\
\text { Infectious tuberculosis }\end{array}$ & $\begin{array}{r}7.2 \\
\text { Silico-tuberculosis }\end{array}$ & 1.0 \\
\hline
\end{tabular}

\section{Summary}

The results of two mass radiography surveys of the African underground employees in a coppermine carried out in 1953 and 1956 are described. At the time of the first survey the prevalence of clinically significant tuberculosis was $25 \cdot 2$ per 1,000 and of silico-tuberculosis 16.9 per 1,000 . The corresponding prevalence rates at the second survey were 3.6 per 1,000 and 1 per 1,000 . This reduction is considered to be partly due to the removal of cases of active tuberculosis found as a result of the first survey and partly to the inauguration of routine pre-employment chest radiography which is estimated to prevent the recruitment of about four cases of tuberculosis per thousand new entrants.

\section{REFERENCES}

Union Government Committee of Enquiry into Pneumoconiosis and Tuberculosis (1955-56). Report of the Departmental Committee of Enquiry into the Relationship between Silicosis and Pulmonary Disability and the Relationship between Pneumoconiosis and Tuberculosis. Part II: The Relationship between coniosis and Tuberculosis. Part is and Tuberculosis, March, 1956.

Pneumoconiosis and Tuberculosis, March,
Viljoen, J. H. (1957). S. Afr. med. J., 31, 316. 